DOI 10.4467/25439561KSR.18.014.9372

KATARZYNA DUDA (D) https://orcid.org/0000-0001-5303-3760

Uniwersytet Jagielloński

Kraków

\title{
(A)HEROIZM ŻYCIA CODZIENNEGO (NA PRZYKŁADZIE WYBRANYCH UTWORÓW WSPÓŁCZESNEJ LITERATURY ROSYJSKIEJ)
}

\author{
(NON)HEROISM OF EVERYDAY LIFE \\ (ON THE EXAMPLE OF CHOSEN COMPOSITIONS \\ IN RUSSIAN MODERN LITERATURE)
}

Streszczenie

Prezentowany tekst został podzielony na dwie części: teoretyczną, w której dokonano próby zdefiniowania pojęć takich jak „heroizm”, „(a)heroizm”, codzienność, współczesna literatura rosyjska oraz praktyczno-opisową, gdzie uwidacznia się odniesienie podanych wyżej pojęć do sfery powszedniości, tę ostatnią umieszczając w beletrystycznych przekazach dzieł rosyjskich powstałych głównie w XXI wieku. Autorzy powieści i opowiadań ukazują, iż bohaterstwo bądź też jego przeciwieństwa - tchórzostwo, ucieczka od wolności - mogą przejawiać się nie tylko w warunkach ludobójstwa (komunizm, łagry, tortury, aresztowania), ale również w powszedniości, kiedy człowiek musi podejmować walkę z cierpieniem, chorobą, niespełnioną miłością... Trudności życia codziennego, co podkreślają pisarze rosyjscy, także ujawniają różnorodne postawy: od życia skupionego zaledwie na własnych potrzebach aż do zupełnego poświęcenia się innym, przy czym walka o codzienną egzystencję nie jest wcale łatwiejsza niż wojna z okupantem. To, co najważniejsze w codzienności, to oparcie się na wartościach, trudny wybór między dobrem a złem.

\section{Abstract}

The following article is divided into two parts. The first, theoretical part, is connected with an attempt of defining expressions such as "heroism", "everyday life", "modern Russian 
literature". The second part shows how these expressions are reflected in short stories and novels written by Russian authors after the collapse of communism. The authors try to prove that bravery can exist not only during wars, in concentrations camps, in special Soviet psychiatric prisons where dissidents were sent, but also in our common life. Not only are people described in the novels as cowards, informers and enemies but they are real heroes as well. They struggle with fatal diseases, poverty, death, the stupidity of other people. They look after their ill children, old parents meanwhile overcoming different obstacles and barriers. It turned out that the struggle for everyday existence is not easier than the war with invaders. As far as the everyday life is concerned, moral values and difficult choices are the most important.

Słowa kluczowe: heroizm codzienności, zmagania z rzeczywistością, współczesna literatura rosyjska

Keywords: everyday heroism, struggle with reality, modern Russian literature

Zaprezentowane w poniższym tekście problemy i tematy wymagają dookreślenia pewnych pojęć teoretycznych, takich jak „codzienność”, „heroizm/aheroizm”, „literatura współczesna”. Tym ostatnim terminem określać będziemy utwory beletrystyczne powstałe po upadku Związku Radzieckiego. Do badań włączono także teksty powstałe już w XXI wieku i zaliczane do tzw. najnowszej literatury rosyjskiej. To ostatnie określenie wydaje się być nietrudne w zdefiniowaniu, czego powiedzieć nie możemy w odniesieniu do słów „,codzienność” oraz „heroizm”. Na pozór ich połączenie wygląda na sprzeczność, zapowiadając metaforyczność dyskursu wynikającą z połączenia tego, co w owym złączeniu staje się niespójne, czy wręcz nawet mało logiczne. Literatura rosyjska XX wieku, zwłaszcza ta zakazana, „źle widziana” przez oficjalną ideologię, nauczyła czytelnika dostrzegać heroizm w piekle łagrów, $\mathrm{w}$ sprzeciwie wobec totalitarnej przemocy, w organizowaniu oporu przeciw utopii komunistycznej, w walce z ,brunatnym totalitaryzmem" podejmowanej w okresie II wojny światowej. W związku z powyższym, ludzie przystępujący do obrony wiary, religii, postrzegani byli jako męczennicy, tych zaś, którzy organizowali demonstracje, akty sprzeciwu, zwykło się nazywać dysydentami, buntownikami, czy przynajmniej kontestatorami. Trzeba pamiętać, że każdy przejaw buntu i kontestacji mógł zakończyć się torturami, osadzeniem w łagrze, zamknięciem w więziennym zakładzie psychiatrycznym. Akt odwagi, męstwa wiązał się zatem nieodłącznie z podjęciem ryzyka. Tak pojęty heroizm nazwać możemy, na nasz użytek, heroizmem w czystej postaci, heroizmem niemal „sterylnym” w swym znaczeniu, wydobytym z ,retorty” badacza tego fenomenu. Tu zaznaczyć należy od razu, że pojmowany tak heroizm znajduje wyraz również we współczesnej literaturze rosyjskiej, często powracającej 
do tematyki łagrów, terroru, Wielkiej Wojny Ojczyźnianej. Pretendując do miana obiektywnego opisu, reinterpretacja wydarzeń odbywa się z dystansu czasowego, z pozycji nieujawniającego emocji obserwatora. Nieraz autorzy, w jednym utworze, łączą dzień dzisiejszy z przeszłością, pokazując bądź odcięcie się od balastu dziejów, bądź konsekwencje tego, co minione dla tego, co bieżące (tak dzieje się na przykład w wybranych przez nas powieściach Ludmiły Ulickiej - Zielony namiot (Зеленый шатёр), Mariny Stiepnowej Kobiety Lazarza (Лазаревы женщины) czy Michaiła Szyszkina Nie dochodza tylko listy nienapisane - Письмовник). Inni twórcy celowo zestawiają teraźniejszość z przeszłością, podkreślając, jak bardzo ta ostatnia zdeterminowała współczesność (Jest nос - Время ночь Ludmiły Pietruszewskiej oraz Rodzina Jottyszewów - Ёлтышевы Romana Sienczina і Eигора ро deszczu - Европа после дождя Aleksieja Jewdokimowa).

W badaniach na temat heroizmu skoncentrujemy się na zmaganiach człowieka z nieprzychylną mu codziennością, z naturą, na pokonywaniu barier i trudności, na obronie ważnych ideałów i słusznych wartości, na podnoszeniu się z upadku albo niemożności podniesienia się z niego, na byciu zniewolonym przez własną niemoc psychofizyczną i przełamywaniu tego zniewolenia, borykaniu się z przeciwnościami losu i, albo poddawaniu się im, albo stawianiu im czoła. Interesować nas będzie przy tym nie środowisko oligarchów, Nowych Rosjan, mieszkańców Rublowki i „sfery glamour", ale tzw. statystyczni obywatele, niczym się niewyróżniający, którzy dzięki uczynkom moralnym bądź niemoralnym pragną utrzymać się na powierzchni życia i uchronić swą godność. Pojmować więc będziemy heroizm zgodnie z ustaleniami Philipa Zimbardo, który pisze:

„W każdym z nas czai się potencjalne zło, ale i każdy ma w sobie uśpionego bohatera, który czeka na odpowiednią chwilę. Na moment, gdy komuś dzieje się zło. I wtedy może stanąć złu na drodze, powstrzymać je. Bo antidotum na zło jest heroizm, ale także codzienne, zwykłe bohaterstwo"'.

Po okrucieństwach Oświęcimia i Kołymy wszelkie inne zło przez wiele lat traktowano jako banalne. Banalny może też być heroizm, ale:

„Banalność heroizmu sugeruje, że wszyscy potencjalnie jesteśmy bohaterami czekającymi w życiu na moment, gdy zrobimy coś heroicznego. Decyzja, by działać heroicznie jest wyborem, do którego wielu z nas jest powoływanych tylko w pewnych momentach życia. Ujmujemy heroizm jako uniwersalny atrybut ludzkiej istoty, nie zaś jako rzadką cechę kilku zaledwie wybrańców. W ten sposób heroizm staje się czymś, co

${ }^{1}$ Cyt. za: D. Wyspiański, Heroizm dnia codziennego według Philipa Zimbardo, „Charaktery” (Kielce) 2015, nr 11, s. 22. 
potencjalnie leży w zasięgu możliwości każdego człowieka, być może skłaniając większość z nas, by odpowiedzieć na to wyzwanie"2.

A zatem heroizm to wbudowany we wnętrze człowieka kompas wyborów moralnych, to szczególna umiejętność zachowania się w sytuacjach trudnych. Zgodnie ze spostrzeżeniami Katarzyny Kucewicz:

„Heroizm nie jest cechą stała, tylko zachowaniem, które może uaktywnić się w nas pod wpływem bodźca wywołującego sytuację zagrażająca. Czyli osoba, która w swoim życiu miała to szczęście nie brać udziału w żadnych trudnych przedsięwzięciach, może również mieć w sobie bohaterstwo, ale uśpione i nigdy nie wydobyte. Może też w danej sytuacji wykazać się heroiczną postawą, a już w innej równie trudnej nie"’.

W części teoretycznej rozważań pozostała nam jeszcze próba określenia codzienności. Definicji takich jest wiele. Tu, bazując na ustaleniach Piotra Sztompki i Rocha Sulimy, przedstawimy taką, która współgra z przytoczonymi powyżej rozważaniami o heroizmie codzienności. Ten heroizm codzienności, tak samo jak antropologia codzienności może zaczynać się już w przestrzeni najbardziej znanej i „oswojonej” - w domu. Zdaniem R. Sulimy, antropolog codzienności sporządza specyficzne sprawozdania, „raporty z życia”, czując się zarazem „swojsko” i „obco” w codzienności, potrafi fascynować się dramatami i banałami ${ }^{4}$. Spośród wielu cech codzienności, podanych przez P. Sztompkę, wybieramy te, które w sposób najistotniejszy wiążą się z przyjętym przez nas analityczno-interpretacyjnym modelem opisu codzienności w beletrystyce rosyjskiej. Według P. Sztompki życie codzienne to:

- zawsze życie w relacjach z innymi, wobec innych,

- zdarzenia powtarzalne, nieraz cykliczne, rutynowe,

- życie codzienne często przybiera formy wykonywane według bezrefleksyjnie wykonywanego scenariusza,

- życie codzienne angażuje naszą cielesność, wyposażenie biologiczne ze wszystkimi jego ograniczeniami, słabościami i ułomnościami,

- życie codzienne jest zlokalizowane w przestrzeni (dom, kościół, ulica) decydującej o jego treści i charakterze,

- epizody życia codziennego mają pewną trwałość,

- życie codzienne ma często charakter bezrefleksyjny, niemal automatyczny,

${ }^{2}$ Ibidem, s. 20.

${ }^{3}$ K. Kucewicz, Heroizm dnia codziennego, [w:] http://katarzynakucewicz.blox.pl/2012/12/Heroizm-dnia-codziennego... [dostęp: 30.03.2016].

${ }^{4}$ Zob. R. Sulima, Antropologia codzienności, Kraków, Wydawnictwo Uniwersytetu Jagiellońskiego, 2000, s. 8 . 
- codzienność jest ściśle związana ze spontanicznością i emocjami wyrażanymi przez nas ${ }^{5}$.

Do powyższego dodać należy jeszcze spostrzeżenie R. Sulimy, iż wspomniane raporty sporządzane przez antropologa codzienności „wystawiają się na najtrudniejszą próbę, czyli próbę ‘dawania świadectw', a w tym zakresie najdalej poszła literatura piękna".

W ramach literatury pięknej heroizm codzienności ukazany jest najbardziej szczerze i spontanicznie w pamiętnikach, dziennikach i listach. Jeśli zgodzimy się $\mathrm{z}$ tą teza, to opowiadanie L. Pietruszewskiej zatytułowane Jest noc okaże się najlepszą jej egzemplifikacją. Jednym z wyróżników tego utworu jest zdeterminowanie przez dzieje, przez historię, choć podkreślić należy, że Pietruszewska nie przejawia większego zainteresowania socjalno-polityczną sferą życia ${ }^{7}$. Ten aspekt jest jednak stale w jej prozie obecny, ale przejawia się nie w skali globalnej, lecz w swego rodzaju mikroświecie, w przygnębiających warunkach codzienności. Podkreśliwszy wyżej, iż w rozumieniu heroizmu mieści się obrona wartości i idei uznanych za pożądane, zestawić można opowiadanie Pietruszewskiej z utworem nestorki radzieckiego feminizmu Aleksandry Kołłontaj Miłość trzech pokoleñ ${ }^{8}$ (Любовь трех поколений). Stojąca zaledwie na progu epoki komunistycznej A. Kołłontaj przedstawia (tak samo jak Pietruszewska) życie babki, matki i córki, u których miłość może być zastąpiona pracą i oddaniem się budowaniu „szczęśliwego jutra”. Spoglądająca na rzeczywistość popieriestrojkową Pietruszewska ukazuje, do czego doprowadziły hasła bolszewików o równouprawnieniu kobiet, o ich wyzwoleniu z pęt życia domowego. Kobiety uległy maskulinizacji. Na pierwszy rzut oka nie potrzebują mężczyzn, choć tak naprawdę stale marzą o wielkiej miłości.

Nastapił więc chaos w świecie wartości. Podkreśla to Pietruszewska w tych partiach utworu, w których główna bohaterka - Anna Andrianowna (w rzadkich, wolnych chwilach pisząca wiersze) porównuje się do Anny Andriejewny Achmatowej. Czyni to zazwyczaj bezpośrednio, na przykład wtedy, gdy w swym pamiętniku z sarkazmem zanotuje:

${ }^{5}$ Zob. P. Sztompka, Życie codzienne - temat najnowszej socjologii, [w:] Socjologia codzienności, red. P. Sztompka, M. Bogunia-Borowska, Kraków, Wydawnictwo Znak, 2008, ss. 24-25.

${ }^{6}$ R. Sulima, Antropologia codzienności..., op.cit., s. 9.

${ }^{7}$ Zob. J. Sałajczykowa, Dziesięciolecie przemian. Proza rosyjska lat 1985-1995, Gdańsk, Wydawnictwo Uniwersytetu Gdańskiego, 1998, s. 55. O życiu i twórczości Pietruszewskiej zob. H. Waszkielewicz, Чернушная и прекрасная. Twórczość Ludmity Pietruszewskiej, Kraków, Collegium Columbinum, 2007.

${ }^{8}$ Zob. Э. Шорэ, Судьба трех поколений, или От очарования к разочарованию (по произведениям А. Коллонтай и Л. Петрушевской), [w:] http://www.a-z.ru/women_cdtm1/h 1/preobrazh_5_ 1997_1.htm [dostęp: 25.03.2016]. 
„Mówiłam to wszystko tylko dlatego, żeby wstrząsnąć, zaszokować, serce moje spływało krwią, matka świr, a syn w ciemnicy, pomódlcie się za mnie wszyscy, jak pisała genialna Anna"

a w stwierdzeniu tym znajdujemy odwołanie do fragmentu Requiem (Реквием) Achmatowej:

„Syn w więzieniu, mąż w mogile./ Pomódlcie się za mnie chwilę"10.

W opowiadaniu podkreśla się antyheroizm współczesności w porównaniu ze strasznym okresem jeżowszczyzny: pierwszy mąż Achmatowej - Nikołaj Gumilow został rozstrzelany za udział w spisku białogwardyjskim, ,przypadkowy” mąż Anny Andrianownej odszedł z inną kobietą, syn XX-wiecznej poetessy Lew był trzykrotnie osadzany w łagrach za pragnienie mówienia prawdy, zaś potomek bohaterki Pietruszewskiej odsiaduje wyrok w więzieniu, skazany za pobicie kolegi i rozbój. Sam tytuł opowiadania Pietruszewskiej Jest noc nawiązuje do rozmowy Achmatowej z Izaakiem Berlinem, w której „carskosielska grzesznica” wspomina szczęśliwe, przedrewolucyjne życie w Petersburgu, natomiast to, co nastapiło po rewolucji jest dla niej nieodmiennie pogrążaniem się w mroku, ciemną nocą - ,samotnością i izolacją zarówno w planie kulturowym, jak i osobistym" "11. Dla Anny Andrianowny noc jest zaledwie czasem wytchnienia - od opieki nad wnukiem, zakupu deficytowych produktów, prozy życia...

Bohaterka Pietruszewskiej przegrywa walkę z codziennością: walkę o kromkę chleba, o chwilę spokoju, o przetrwanie. Poświęciła się wnukowi, rezygnując z dobrych relacji z matką i córka, chociaż właśnie w dobru współistnienia mogłaby osiągnąc tożsamościowy spokój ${ }^{12}$. Nie przyniesie żadnych efektów chęć przywrócenia choćby poprawnych układów z Serafiną i Aloną. Czasu nie da się ani cofnąć, ani zatrzymać. Ofiara Anny okazuje się zbyteczna.

Upadło kilkudziesięcioletnie marzenie o komunizmie, tak samo jak nie spełniło się pragnienie Jołtyszewów dotyczące budowy nowego domostwa na dalekiej, syberyjskiej wsi, bowiem „Budowa utknęła na zalewaniu fundamentu”13. O tym przeko-

${ }^{9}$ L. Pietruszewska, Jest noc, tłum. J. Czech, Wołowiec, Wydawnictwo Czarne, 2012, s. 69.

${ }^{10}$ A. Achmatowa, Requiem, [w:] eadem, Droga wszystkiej ziemi. Poezja-proza-dramat, wybrał, przeł. i komentarzami opatrzył A. Pomorski, Warszawa, OPEN Wydawnictwo Naukowe i Literackie, 2007, s. 86.

${ }^{11}$ И. Берлин, Воспоминания об Анне Ахматовой, Москва, Советский писатель, 1991, s. 436459.

${ }^{12}$ Zob. B. Darska, Życie bezradne (L. Pietruszewska, ,Jest noc”), [w:] http://onet.p1/2012/05/27// zycie-bezradne..., [dostęp: 25.03.2016].

${ }^{13}$ R. Senczin, Rodzina Joltyszewów, thum. M. Hornung, Warszawa, Noir Sur Blanc, 2015, s. 11. 
nuje nas utwór Senczyna Rodzina Jołtyszewów. Tu z kolei widoczne są paralele z powstałym w 1929 roku Wykopem (Котлован) Andrieja Płatonowa: ogólnoproletariacki gmach nigdy nie powstanie, bo wznoszony jest na krzywdzie i śmierci ludzi. Jołtyszewowie z początków XXI wieku są wszak potomkami budowniczych „wykopu" - wyrzekają się tradycji, nie umieją pracować, za to szybko uczą się handlować bimbrem i mścić za swe nieudane istnienie. Pogrążają się w marazmie, w rutynie codzienności, która ich - dosłownie i w przenośni - zabija:

„Przystali na jej [Walentyny - K.D.] wariant. Mąż z poczuciem beznadziei, syn, jak się wydawało, z obojętnością. Walentyna przebrała się w szlafrok i poszła do kuchni. Robić kolację. Wyjęła spod zamrażarki rozmrożony kawałek wieprzowiny, nastawiła wodę na kolanka. Wybrała sobie w koszyku cebulę. Jej ruchy były odmierzone, wyuczone po dziesiątkach lat powtarzania..."14.

Jeśli zadaniem badacza codzienności jest, zgodnie z przytoczoną definicją R. Sulimy, sporządzanie raportów, to przedmiot badań (codzienność w jej (anty)heroizmie) okaże się najlepiej odzwierciedlony (postrzegany) nie tylko w dziennikach i diariuszach, ale również w listach. Widać to w powieści epistolarnej M. Szyszkina Nie dochodza tylko listy nienapisane. Listy, podkreślmy - listy tradycyjne, pisane piórem na nieraz specjalnie przystosowanym do tego celu papierze - to obecnie forma zanikająca, wypierana przez sms-y, maile, pozwalająca znacznie skrócić czas dotarcia do adresata, ale za to zatracająca indywidualność piszącego, wejrzenie (na przykład poprzez „,rozedrgany” charakter pisma) w niespokojne, zatroskane, nierzadko wręcz zrozpaczone wnętrze nadawcy. „Po co się pisze?” - pyta główny bohater Szyszkina, dodając zaraz: „- Póki się pisze, póty się żyje. Jeżeli czytasz te słowa, to znaczy, że termin śmierci został odroczony [...]"15. Wiadomość od kogoś staje się więc wiadomością dla kogoś, ważnym przekazem, antidotum na strach i niepokój. Wizualizacja piszącego, przywołanie jego rzeczywistego wizerunku nie pozwalają zapomnieć, są stałym elementem podtrzymującym pamięć i zmniejszającym tęsknotę. Wykreowany przez Szyszkina Wołodia napisze również w jednym z listów słowa, podkreślające heroizm codzienności:

„Szukałem odpowiedzi albo chociaż właściwie postawionego pytania w książce jakiegoś mędrca, ale oni wszyscy chórem nawołują, żeby żyć dniem dzisiejszym, cieszyć się chwilą i tym, co przemija. Ale to trzeba umieć"16.

${ }^{14}$ Ibidem, s. 28.

${ }^{15}$ M. Szyszkin, Nie dochodza tylko listy nienapisane, thum. M. Hornung, Warszawa, Noir Sur Blanc, 2013, s. 58.

${ }^{16}$ Ibidem, s. 143. 
Heroizm ów polega na tym, że trzeba nauczyć się życia, a to najtrudniejsza ze sztuk. Życie jest równoznaczne życiu w czasie ${ }^{17}$.

Człowiek stara się pokazać, że panuje nad całym czasem, a więc jego trzema wymiarami ${ }^{18}$, chce udowodnić, że będąc herosem codzienności, udaje mu się pokonać czas. Ta próba jego pokonywania wpisana jest w naszą powszedniość. A zatem: techniki oświetleniowe pozwoliły „pokonać” ciemność (dzień - noc), techniki grzewcze - zimno (pory roku), środki konserwujące - psucie się żywności, kosmetologia - starzenie się ciała (przykładem tego jest Galina Pietrowna z Kobiet Łazarza M. Stiepnowej), inżynieria genetyczna - zmienić cykle życiowe i procesy życiowe istot żywych ${ }^{19}$. Człowiek stale pragnie udowodnić swe bohaterstwo (antybohaterstwo?), władzę i moc sprawczą. Wołodia na przykład (Nie dochodza tylko listy nienapisane) znalazł puszkę po cukierkach i chciał w niej „,zakonserwować” to, co dla niego najdroższe:

„Więc trzeba było włożyć do puszki coś należącego do mamy. Wyjąłem po kryjomu z albumu jej zdjęcie i też zakopałem. Potem doznałem olśnienia, że posiadam oto niesamowitą władzę - zostaną tylko ci, których zabiorę ze sobą do swojej puszki”20.

Wynika z tego, że człowiek zagubił bazę, opokę, na której można by się oprzeć, imperatyw moralny, zasadę porządkującą świat, to, co Małgorzata Bogunia-Borowska nazywa bezpieczeństwem ontologicznym ${ }^{21}$. Stwierdzenie to poświadcza inny współczesny pisarz rosyjski Aleksiej Jewdokimow w opowiadaniu Europa po deszczu:

„(...) nikt nie jest winny. Nikt i nic, bo nie ma żadnej reguły, która by to wszystko determinowała [podkr. K.D.]"22.

Jeżeli nie ma reguł, to każdy może krzywdzić każdego, wymierzać moralne ciosy, zadawać ból... Bez ustanowienia ściśle uporządkowanej hierarchii wartości istota ludzka staje się „Człowiekiem z Podziemia” płatającym zbrodnicze figle po to tylko, aby zaznaczyć swą obecność, aby pokazać, iż podarowana nam wolna wola może być wykorzystana w każdym celu, żeby udowodnić, że człowiek nie jest jedy-

${ }^{17}$ Zob. M. Błaszkowski, Czas. Czy rzeczywiście przemija?, [w:] http://marekblaszkowski.salon24. pl/137517.czas-czy-rzeczywiscie [dostęp: 14.02.2016].

${ }^{18}$ Zob. Ch. Gosden, Social Being and Time, Oxford, Blackwell, 1994, s. 211.

${ }^{19}$ Zob. J. Kopka, Czas a moralność. Od filozoficznych do socjologicznych koncepcji czasu, „Acta Universitatis Lodziensis”. „Folia Sociologica”, 2012, nr 7, s. 40.

${ }^{20}$ M. Szyszkin, Nie dochodza tylko listy nienapisane ..., op.cit., s. 113.

${ }^{21}$ Zob. M. Bogunia-Borowska, Fundamenty dobrego społeczeństwa. Wartości, red. M. BoguniaBorowska, Kraków, Znak, 2015, s. 234.

${ }^{22}$ A. Jewdokimow, Europa po deszczu, [w:] Moskwa Noir, red. N. Smirnowa, J. Goumen, thum. E. Skórska, Warszawa, Wydawnictwo Claroscuro, 2011, s. 250. 
nie klawiszem fortepianu. We wspomnianym opowiadaniu Jewdokimow przytoczy następujący fragment rozmowy między dwoma bohaterami:

„[...] - Właśnie dlatego do was wszystkich przychodzę - żebyście choć na koniec się nad tym zastanowili. Że nie ma reguł nawet tutaj. I nawet jeśli przez cały czas miałeś szczęście, to jeszcze nie gwarantuje ci niczego. Niczego...

- Aha - Feliks z kolei pochylił się odrobinę, zmuszając Pawła do odsunięcia się.

- I ty wziąłeś na siebie rolę przeznaczenia [podkr. K.D.]”23.

Jeżeli zatem uzurpujesz sobie prawa Stwórcy, to wolno ci wszystko, wolno, zwłaszcza działając $\mathrm{w}$ imię bliżej niedookreślonego zbawienia świata, popełnić zbrodnię, chcąc stworzyć świat bez zbrodni. Obywatele współczesnego świata nie dostrzegają jednak błędu w swym rozumowaniu, nie uświadamiają sobie własnych grzechów i dlatego nie doznają odkupienia. Pozostają na poziomie sfery ratio, gdyż zabrakło im odniesienia do transcendencji. $Z$ tego samego względu w powieści R. Sienczina Rodzina Jołtyszewów postawiony na miejscu przedrewolucyjnej cerkwi klub, strawiony przez pożar, zostanie odbudowany, mimo petycji starszych mieszkańców wioski Muranowo, aby wznieść tam świątynię. Buta i pycha człowieka szybko zostają jednak przełamane. Według Romana Ingardena, dopiero gdy jesteśmy świadkami tego, jak w gruzy rozpadają się imperia, które wydawały się niewzruszone, jak dzieła ludzkości, które objawiały jej geniusz przez całe pokolenia z biegiem czasu starzeją się nieuchronnie - wówczas widzimy, że ów trwały byt, który, jak się nam zdawało, sami stanowimy, jest przemijający i ułomny i domaga się oparcia, podpory ${ }^{24}$. Taką podpora, tym, który zarządza czasem i przestrzenią okazuje się, co unaocznia M. Szyszkin, ten, którego nazwał z pozoru abstrakcyjnym ON. To ON zwraca się do Saszy dobiegającej kresu życia: Już czas" ${ }^{25}$.

ludzie stają się tym, czym byli zawsze - ciepłem i światłem. Zaraz idziemy.

Identyczny motyw odnajdujemy w utworze Kobiety Lazarza, kiedy Lidoczka, po śmierci, spotyka swoich zmarłych rodziców: również wtedy ciepło i światło zastępują chłód doczesności.

W rozważaniach o heroizmie codzienności, o bohaterach czy też antyherosach dnia powszedniego, trudno pominąć temat choroby, cierpienia i związaną z nimi refleksję nad sensem ludzkiej egzystencji. Motyw choroby, w różnych jej postaciach i przejawach, występuje we wszystkich wskazanych przez nas utworach. W powieści

${ }^{23}$ Ibidem, s. 254.

${ }^{24}$ Zob. R. Ingarden, Ksiqżeczka o człowieku, Kraków, Wydawnictwo Literackie, 1987, ss. 49-50.

${ }^{25}$ M. Szyszkin, Nie dochodza tylko listy nienapisane..., op.cit., s. 274. 
Nie dochodza tylko listy nienapisane są to nowotwór matki Saszy i udar jej ojca, w książce Kobiety Lazarza - geriatryczny dyskomfort Marusi i Lindta, w Rodzinie Joltyszewów - insulinooporna postać cukrzycy, w Zielonym namiocie - białaczka Olgi, autyzm Briańskiego... Przypadki beznadziejne, bezwyjściowość sytuacji, mechanizmy zachowań pacjentów i ich bliskich - interesują autorów najbardziej. Podążają tu więc tropem Maxa Schelera, twierdzącego, iż centralną częścią koncepcji i wskazań przekazanych człowiekowi przez wielkie postacie religii i filozofów była zawsze i wszędzie na całym świecie jakaś nauka o sensie bólu i cierpienia. Na niej wspierało się zalecenie, aby należycie potraktować cierpienie, aby właściwie je znosić bądź by je likwidować26.

M. Szyszkin na przykład, pisząc o guzach złośliwych, przypadłościach związanych z układem krążenia, zdaje sobie sprawę, że choroba przewlekła wiąże się przede wszystkim z faktem, że dolegliwości zdrowotne nie mijają ale przeciwnie nasilają się w miarę upływu czasu. Powoduje to negatywne skutki w każdej niemal sferze życia: obniża się fizyczna sprawność organizmu („Babcia zachorowała. Właściwie poślizgnęła się w zimie na oblodzonym miejscu koło poczty, upadła i złamała sobie kość biodrową. I już nie wstała, leżała kilka miesięcy, bezradna i coraz słabsza" ${ }^{27}$ ), pogarsza się samopoczucie, zmienia się rytm życia, wygląd zewnętrzny, maleje aktywność życiowa („Trzeba wyjmować spod niej pieluchy, zakrapiać oczy wodą jałowa, żeby nie wyschły. Zwilżać wyschnięte wargi. Obracać. Myć" ${ }^{28}$ ), zmienia się jakość relacji interpersonalnych, zmianie ulega także hierarchia wartości ${ }^{29}$. Ten ostatni czynnik jest szczególnie istotny, gdy zwrócimy uwagę na to, iż w czasach współczesnych wielu psychologów rozumie zdrowie właśnie w kategoriach wartości. W tej koncepcji zdrowie i choroba nie są umieszczone paralelnie, ale podobnie jak inne wartości, mają swój znak i traktowane są rozłącznie. Zatem zdrowie jest wartością pozytywną, do której człowiek dąży, a jego przeciwieństwo - choroba wartością negatywną, której człowiek unika ${ }^{30}$.

Autorzy wzmiankowanych tekstów literackich nie stronią od opisów bólu, zmagań z własnym, posłusznym dotąd ciałem, słabością. O wiele jednak ważniejsze są dla nich odczucia bohatera, to, co dzieje się w jego wnętrzu, jakie wrażenia i emocje współgrają w walce z chorobą, a jakie potęgująjej nasilenie. Psychofizyczna jedność człowieka implikuje bowiem istnienie wzajemnych wpływów między sferą somatyczną i psychiczną. Zgodnie z tą zasadą każde zaburzenie czynności ustroju znajdu-

${ }^{26}$ Zob. M. Scheller, Cierpienie, śmierć, dalsze życie. Pisma wybrane, thum. A. Węgrzycki, Warszawa, PWN, 1994, s. 3.

${ }^{27}$ M. Szyszkin, Nie dochodza tylko listy nienapisane ..., op.cit., s. 115.

${ }^{28}$ Ibidem, s. 171.

${ }^{29}$ Zob. np. M. Bąk-Sosnowska, Choroby przewlekte - dlaczego zmieniaja życie i jak sobie z nimi radzić, [w:] http://zakladpsychologii.sum.edu.pl/?r=artykul/view\&id=26 [dostęp: 28.12.2015].

${ }^{30}$ Zob. J. Heszen, H. Sęk, Psychologia zdrowia, Warszawa, PWN, 2009, s. 211. 
je swoje odzwierciedlenie w obszarze psychiki i zachowania się jednostki ${ }^{31}$. I tak, ujmowanie schorzenia $\mathrm{w}$ kategoriach straty sprawia, iż chory koncentruje się na związanych z nim ograniczeniach i deficytach, które w jego odczuciu są niemożliwe do pokonania ${ }^{32}$. Byłby to zatem pewien szczególny rodzaj aheroizmu, ale wynikający nie z wyboru czy tchórzostwa jednostki, lecz z zewnętrznej wobec chorego płaszczyzny zmienności dotychczasowego statusu i położenia. Rezultatem przyjęcia takiej postawy są uczucia przygnębienia i smutku, tendencje autodestrukcyjne, poczucie pustki oraz żałoba związana z utratą sprawności bądź danej funkcji organizmu. Nierzadko dołącza do nich, w dalszych etapach choroby, rozdrażnienie, niepokój, a nawet agresja. Taka postawa charakteryzowała zachowanie, cierpiącej na raka piersi, matki Saszy (Nie dochodza tylko listy nienapisane):

„Zaczęła na mnie krzyczeć, że nie zależy mi na niej i mam w nosie, że ona tu [w szpitalu - K.D.] dostaje szału. Mama zawsze była taka opanowana, ale choroba zupełnie ją zmieniła. A to lekarzy uważała za kiepskich specjalistów, a to znów niewłaściwe były badania i dieta..." ${ }^{\prime 3}$.

Interpretowanie choroby w kategoriach wartości występuje dopiero w dalszych etapach jej trwania („Choroby są konieczne, choroby pomagaja, człowiek! Jeżeli tak cierpi nie boi się odchodzić" ${ }^{34}$ - Nie dochodza tylko listy nienapisane) i jest konsekwencją zaakceptowania choroby oraz wynikających z niej ograniczeń. Przyjęcie takiej postawy wiąże się z refleksją nad własnym życiem, z pozytywnym doświadczeniem, ponadto w sposób korzystny rzutuje na proces dojrzewania osobowości i kształtowania relacji z innymi ludźmi ${ }^{35}$. Sytuację choroby postrzega się w związku z tym jako okazję do urzeczywistnienia wartości postawy i realizowania bytu osobowego $^{36}$. Przykładem takiej duchowej transformacji (od egoizmu aż po altruizm) na skutek cierpienia jest ojciec Saszy (Nie dochodza tylko listy nienapisane), który po pokonaniu pierwszego wylewu zanotował w swoim dzienniku:

„Wyszedłem wieczorem na spacer wokół domu. Jak dobrze jest po prostu tak przejść się samotnie! Kiedy wylew dopadnie człowieka, ten od razu nabiera rozumu, zaczyna się orientować, co dobre" ${ }^{37}$.

${ }^{31}$ Zob. K. Czubalski, Wpływ choroby na stan psychiczny i zachowanie człowieka chorego. Sztuka leczenia, Gdańsk, Gdańskie Wydawnictwo Psychologiczne, 1995, s. 57.

${ }^{32}$ Zob. M. Płuciennik, Pacjent kontra choroba, czyli słów kilka o postawach wobec choroby, [w:] http://www.psychologia.net.pl/artykul.php?level=621 [dostęp: 03.01.2016]; tam dalsza bibliografia.

${ }^{33}$ M. Szyszkin, Nie dochodza tylko listy nienapisane..., op.cit., s. 213.

${ }^{34}$ Ibidem, s. 230.

${ }^{35}$ Zob. S. Steuden, Z psychologicznej problematyki zdrowia i choroby, thum. W.P. Oleś, Lublin, Towarzystwo Naukowe KUL, 2002, s. 87.

${ }^{36}$ V.E. Frankl, Homo patiens, thum. M. Phuciennik, Warszawa, Instytut Wydawniczy PAX, 1998, s. 154.

${ }^{37}$ M. Szyszkin, Nie dochodza tylko listy nienapisane..., op.cit., s. 265. 
Znaczenie postaw wobec choroby ujawnia się szczególnie wtedy, kiedy są one negatywne, gdy poprzez to, iż utrudniają przystosowanie się do choroby wpływają także negatywnie na ewaluację jakości własnego życia ${ }^{38}$. Przyjęcie odpowiedniej postawy (rezygnacji, przystosowania się, bądź odwagi i walki z niedomaganiem) nie tylko ułatwia przezwyciężenie ograniczeń, lecz także dzięki osobowej aktywności stawiania czoła doświadczanemu cierpieniu, wpływa na możliwość wewnętrznego rozwoju. Przyjęcie akceptującej i aktywnej postawy wobec własnego cierpienia w sytuacji ciężkiej choroby somatycznej może doprowadzić nie tylko do przetrwania, przyzwyczajenia się, ale również do radości istnienia mimo wszystko. Poglądy te niejako podnoszą wagę postawy wobec własnej choroby, wskazując, iż ma ona nie tylko wpływ na jakość życia człowieka cierpiącego, ale także na czas jego trwania. Silna wola życia i postawiony cel, zwłaszcza związany z miłością do drugich, wyzwala zdolności samolecznicze ${ }^{39}$. M. Szyszkin koncentruje swą uwagę na tej ostatniej postawie, gdyż jest ona z jednej strony trudniejsza do zrealizowania, $\mathrm{z}$ drugiej wskazuje na siłę tkwiącą w ludzkiej psychice. Umiłowanie życia mimo wszystko - tak dałoby się określić zachowanie i sposób bycia niewidomego ojczyma Wołodii (Nie dochodza tylko listy nienapisane):

„Najbardziej denerwował mnie ten niewidomy. Leżę w swoim pokoju, wbity w kąt, z głową pod poduszką, mam dreszcze z poczucia przerażającej ciemności i pustki, a on, pogwizdując, chodzi sobie po przedpokoju, żyje pełnią życia, które mimo ślepoty nie wydaje mu się ciemne i puste! Cóż on takiego widzi tymi swoimi ślepymi oczami, czego ja nie widzę? [podkr. K.D.]. Jakie niewidzialne światy?" ${ }^{40}$.

Taką samą, afirmatywną postawę wobec utrudnionego życia prezentują głuchonieme dzieci z powieści Zielony namiot L. Ulickiej. Ich nauczycielowi - Misze Mieładowowi - wydaje się, iż słyszą lepiej i mówią wyraźniej niż ich zdrowi rówieśnicy.

W swoim oglądzie choroby, zmagania się z bólem, autorzy nie pominęli cierpienia dziecka, a także rodziców, którzy muszą stawić czoło temu tragicznemu faktowi. Najbardziej wyrazista postawę - rozpacz, bunt, psychiczne odrzucenie kolejnego potomka traktowanego jako surogat - reprezentuje matka Saszy (Nie dochodza tylko listy nienapisane), niemogąca pogodzić się ze śmiercią pierworodnego. Informacja o przewlekle chorym dziecku jest jedną z najtrudniejszych wiadomości, jaką mogą otrzymać rodzice. Moment postawienia ostatecznej diagnozy przypada na czas tzw. kryzysu emocjonalnego - przedłużającego się stresu i zmęczenia, depresji połączonej

\footnotetext{
${ }^{38}$ Zob. V.E. Frank1, Homo patiens..., op.cit., s. 155.

${ }^{39}$ Zob. M. Jourard, Diclosing Man to Himself, Toronto, D. Van Nostrand Company, 1968, s. 213.

${ }^{40}$ M. Szyszkin, Nie dochodzq tylko listy nienapisane..., op.cit., s. 142.
} 
z bezradnością ${ }^{41}$. Jeśli rodzice potraktują chorobę dziecka jako krzywdę, mogą zacząć szukać winnych i użalać się nad sobą. Taka postawa rodzi pretensje kierowane do losu, świata, lekarzy:

„On obwinia siebie o to, co się stało. Ona - mnie.

Ada chodzi do lekarza naczelnego, żąda, płacze.

Słychać na korytarzu:

- No niechże pan doktor coś zrobi!"’2.

Rodzicom zatem załamuje się świat oraz dotychczasowy ład w rodzinie. Dla wielu z nich choroba dziecka to osobista, wielka porażka życiowa. Pojawiają się żal, złość, poczucie bezsilności bądź bunt. Wszystko irytuje, nawet najbliżsi ${ }^{43}$. Skutkiem bywają konflikty i coraz większa frustracja. Na ogół taka postawa jest próbą zwrócenia na siebie uwagi. To niewyrażona wprost prośba o pocieszenie, wołanie o pomoc, nieraz ucieczka we własne wnętrze, chowanie się w sobie. Takich mechanizmów zachowania nie można nazwać antyheroicznymi, nie kryją w sobie bowiem braku miłości, chęci pomocy, pragnienia wsparcia. Przeciwnie, są przykładem silnego przywiązania i marzenia o przywróceniu stanu rzeczy sprzed choroby. Antyheroiczna, a nawet więcej: egoistyczna i antypatyczna jest postawa Jewgienii (Zielony namiot), która odejście opóźnionej intelektualnie córki traktuje jako ulgę, jak wybawienie prawie. Kalekie dziecko było dla niej balastem:

„Ciocia przeżyła śmierć córki raczej jak śmierć domowego zwierzątka (...) Wkrótce po wyniesieniu z domu leżanki i dziecięcego krzesełka (...) ciocia uwolniła się od przykrych trosk i z głęboką satysfakcją oraz z cieniem patologicznej dumy od czasu do czasu powtarzała: przydarzyło mi się w życiu tyle nieszczęść, że to się w głowie nie mieści!" 44 .

W przeżywaniu sytuacji trudnych, ale i w dzieleniu radości, wielką rolę odgrywają przyjaciele. Temat przyjaźni włączamy tu dlatego, gdyż, jak twierdził Cyceron Sine amicita vita est nulla ${ }^{45}$ („Nie ma życia bez przyjaźni”), a zatem i życie codzienne, zwłaszcza jeśli jedną z jego cech jest istnienie człowieka w relacjach z innymi ludźmi, byłoby nie do pomyślenia bez przyjaciół. Z punktu widzenia historii przyjaźń najpełniej przejawia swój heroizm w czasie przełomów dziejowych, kiedy

${ }^{41}$ Zob. A. Jędrzejewska, A. Rusinek, Choroba dziecka - krzywda czy wyzwanie?, „Przyjaciel” 2007, nr 2, s. 1.

${ }^{42}$ M. Szyszkin, Nie dochodza tylko listy nienapisane ..., op.cit., s. 171.

${ }^{43}$ Zob. A. Jędrzejewska, A. Rusinek, Choroba dziecka ..., op.cit., s. 2.

${ }^{44}$ L. Ulicka, Zielony namiot, tłum. Redlich, Warszawa, Świat Książki, Warszawa 2013, ss. 477478.

${ }^{45}$ Cyt. za: A. Kojder, Przyjaźń, [w:] Fundamenty dobrego społeczeństwa ..., op.cit., s. 168. 
niejednokrotnie oddaje się własne życie za swoich przyjaciół. Przymioty przyjaźni związane z bohaterstwem, z poświęceniem się dla drugiego kosztem rezygnacji z własnych planów, widoczne są w sytuacjach powszedniości, aczkolwiek same w sobie nie są powszechne. Deficyt więzi przyjacielskich daje o sobie znać zwłaszcza współcześnie, w ponowoczesnym, zglobalizowanym świecie, w którym czas określany przez wymogi korporacyjne, pogoń za pieniądzem, prestiżem..., uniemożliwia zawieranie przyjaźni, a już tym bardziej pielęgnowanie jej, dbanie o nią. Istota ludzka staje się „wydmuszką”, „korpoludkiem/korposzczurem”, samonapędzającym się mechanizmem dążącym do znalezienia się w kręgu celebrytów. W literaturze współczesnej tendencję tę obrazują m.in. Siergiej Minajew w powieści Duchless. Opowieść o nieprawdziwym człowieku ${ }^{46}$ (Дyxless. Повесть о ненастоящем человеке) czy też Wiktor Pielewin w utworze Sok ananasowy dla pięknej dату ${ }^{47}$ (Ананасная вода для прекрасной дамы).

O przyjaźni prawdziwej, nieograniczonej bilansem zysków i strat pisze dziś bodaj najpełniej L. Ulicka. Pisarka zauważa wyraźną rysę w ideologii bolszewickiej powtórne narodziny przyjaźni, która pojawiwszy się w okresie odwilży zapuściła w rosyjskiej glebie tak mocne korzenie, że nie zdołała jej zniszczyć ani breżniewowska stagnacja, ani gorbaczowowska zawierucha. Przyjaźń utożsamiana jest z jednej strony przez Ilję, Sanię i Michę, z drugiej przez Olgę, Tamarę i Połuszkę. W czasie, gdy „dwójmyślenie” stało się norma, gdy prawdziwych znaczeń pozbawiono takie pojęcia jak zaufanie i wiara, przyjaźń pomagała w odbudowywaniu hierarchii wartości, zaczęła wzbogacać relacje interpersonalne, czynić człowieka lepszym, odrywając go od jego samotności. Ten ostatni czynnik ważny był zwłaszcza w Kraju Rad, w którym istota ludzka zatraciła punkty orientacyjne, odniesienie do transcendencji, przyjaciel bowiem to, zdaniem L. Ulickiej, widzialna, ziemska wersja Anioła Stróża. Do przyjaźni zdolni są tylko ci ludzie, którzy są świadomi własnej godności, którzy chronią swoją wolność, czystość, świętość, którzy idą drogą błogosławieństwa i życia, których więź z Bogiem jest silniejsza od najsilniejszej więzi z człowiekiem ${ }^{48}$.

Ulicka postrzega przyjaźń w sensie uniwersalnym. Doceniając jej wartość w totalitaryzmie, przenosi ją poza czas i przestrzeń. Pisarka zdaje sobie sprawę, że zdefiniowanie przyjaźni jest trudne, trudniejsze od określenia miłości, gdzie pierwiastek erotyczny odgrywa rolę niebagatelną, dlatego pisze:

${ }^{46}$ S. Minajew, Duchless. Opowieść o nieprawdziwym człowieku, thum. P. Podmiotło, Warszawa, Wydawnictwo Claroscuro, 2007.

${ }^{47}$ W. Pielewin, Napój ananasowy dla pięknej damy, tłum. E. Rojewska-Olejarczuk, Warszawa, Grupa Wydawnicza Foksal, 2014.

${ }^{48}$ Zob. M. Dziewiecki, Przyjaźń w czasach nieprzyjaznych dla przyjaźni, [w:] http://www.opoka. org.pl/biblioteka/I/IP/md_przyjazn2011_4html [dostęp: 10.09.2015]. 
„Ale co zrobić z przyjaźnią? Nie wspiera jej żaden fundamentalny instynkt [...]. Tak więc przyjaźni nie uzasadnia natura, przyjaźń nie ma żadnego celu, polega tylko na poszukiwaniu bratniej duszy, żeby dzielić z nią przeżycia, myśli, uczucia... [...]. Ale za to szczęście należy przyjaźń karmić czasem własnego jedynego życia: albo pójść na spacer z przyjacielem [...], napić się z nim piwa, nawet jeżeli woli się inne napoje, a piwo lubi przyjaciel, pójść na urodziny do jego babci, czytać te same książki, słuchać tej samej muzyki, żeby w końcu powstała mała, zamknięta i ciepła przestrzeń, w której dowcipy rozumie się w pół słowa, wymiana zdań odbywa się za pomocą spojrzenia, a współdziałanie między przyjaciółmi charakteryzuje taka intymność, jakiej nie da się osiągnąć z istotą innej płci" ${ }^{\prime 4}$.

Przyjaźń, odwrotnie niż miłość, nie wymaga bliskości fizycznej, przestrzennej. Przyjaciele mogą znajdować się na różnych kontynentach (Briański na emigracji w Paryżu, Sania w Stanach Zjednoczonych) i odczuwać więź duchową, mogą nie widywać się przez dłuższy czas, ale ich uczucie pozostaje stabilne - nie waha się od euforii do depresji, jak to bywa w miłosnym uniesieniu. Według Arystotelesa, na którego powołuje się pisarka ${ }^{50}$, przyjaźń to jedna z cnót, chociaż, w przeciwieństwie do cnót kardynalnych, nie jest ona cnotą normatywną ${ }^{51}$. Filozof ten twierdzi także, że istnieje kilka rodzajów przyjaźni: idealna (teleia philia, będąca wartością samą w sobie) oraz takie, z których każda ma spełniać pewien cel (przyjemność lub użyteczność).

Bliskie związki spełniają wiele różnorodnych funkcji psychologicznych. Uczymy się w nich szacunku dla ludzi, dla ich odmienności i odrębności. Przyjaźń zawierana może być na zasadzie tożsamości bądź podobieństwa zainteresowań (artystyczne pasje Ilji, Sani i Michy), bądź na zasadzie ich odmienności (Tamara zafascynowana genetyka, Połuszka sportem), w oparciu o podobne pochodzenie społeczne lub jego zróżnicowanie (Olga - córka aparatczyków partyjnych, Połuszka - reprezentantka ,komunistycznego” proletariatu). Ważny jest tu jednak czynnik dobrowolności.

Heroizm codzienności, dotyczący z pozoru spraw małych, a nawet miałkich, wykazuje jednakowoż fakt, który na co dzień powinniśmy mieć na uwadze: rzeczywistość mieszcząca też sprawy przyziemne, ale ważne, jest nam zadana, a nie dana. Przeto rutyna codzienności nie może przeobrazić się w nudę, a zabiegi o codzienną egzystencję - w dramat. Dojrzenie piękna w sprawach małych, w drobiazgach to też przesłanie ,małego heroizmu” naszych dni. Pokonywanie życiowych

${ }^{49}$ L. Ulicka, Zielony namiot..., op.cit., ss. 510-511.

${ }^{50}$ Ibidem, s. 511.

${ }^{51}$ Zob. Przyjaźń, ,Journal of Consumer Research”, [w:] http://www.eurekalert.org/put_releases/2006-01/uo=p=yf01300,php [dostęp: 12.09.2014]. 
przeszkód, zawirowań, choroby, procesu starzenia się, nieszczęść - to kolejne stadium bohaterstwa w skali mikro. Pamiętać należy nade wszystko o tym, aby współcześnie, stawiając czoła prędkości coraz bardziej przyśpieszającego świata, nie przekształcić miłości, przyjaźni i zaufania w produkt, w towar deficytowy. Z tego też względu wiele utworów współczesnej literatury rosyjskiej brzmi jak antyutopijne ostrzeżenie.

\section{Literatura}

Achmatowa A., Requiem, [w:] eadem, Droga wszystkiej ziemi. Poezja-proza-dramat, thum. A. Pomorski, Warszawa, OPEN Wydawnictwo Naukowe i Literackie, 2007, ss. 82-90.

Bąk-Sosnowska M., Choroby przewlekle - dlaczego zmieniaja życie i jak sobie z nimi radzić, http://zakladpsychologii.sum.edu.pl/?r=artykul/view\&id=26 [dostęp: 28.12.2015].

Błaszkowski M., Czas. Czy rzeczywiście przemija?, http://marekblaszkowski.salon24.p1/137517.czas-czy-rzeczywiscie [dostęp: 16.02.2014].

Czubalski K., Wplyw choroby na stan psychiczny i zachowanie czlowieka chorego. Sztuka leczenia, Gdańsk, Gdańskie Wydawnictwo Psychologiczne, 1995, 321 ss.

Darska B., Życie bezradne (L. Pietruszewska, ,Jest noc”), http://onet.p1/2012/05/27// zycie-bezradne..., [dostęp: 25.03.2016].

Dziewiecki M., Przyjaźń w czasach nieprzyjaznych dla przyjaźni, http://www.opoka.org.pl/biblioteka/I/IP/md_przyjazn2011_4html [dostęp: 10.09.2015].

Frankl V. E., Homo patiens, thum. M. Płuciennik, Warszawa, Instytut Wydawniczy PAX, 1998, 325 ss.

Fundamenty dobrego społeczeństwa. Wartości, red. M. Bogunia-Borowska, Kraków, Znak, 2015, 381 ss.

Gosden Ch., Social Being and Time, Oxford, Blackwell, 1994, 232 ss.

Heszen J., Sęk H., Psychologia zdrowia, Warszawa, PWN 2009, 371 ss.

Ingarden R., Ksiqżeczka o człowieku, Kraków, Wydawnictwo Literackie, 1987, 176 ss.

Jewdokimow A., Europa po deszczu, [w:] Moskwa Noir, red. N. Smirnowa, J. Goumen,

thum. E. Skórska, Warszawa, Wydawnictwo Claroscuro, 2011, ss. 211-253.

Jędrzejewska A., Rusinek A., Choroba dziecka-krzywda czy wyzwanie?, „Przyjaciel” 2007, $\mathrm{nr} 2$.

Jourard M., Diclosing Man to Himself, Toronto, D. Van Nostrand Company, 1968, 236 ss.

Kopka J., Czas a moralność. Od filozoficznych do socjologicznych koncepcji czasu, „Acta Universitatis Lodziensis”. Folia Sociologica 2005, nr 5, ss. 38-50. 
Kucewicz K., Heroizm dnia codziennego, http://katarzynakucewicz.blox.pl/2012/12/ Heroizm-dnia-codziennego... [dostęp: 30.03.2016].

Minajew S., Duchless. Opowieść o nieprawdziwym człowieku, tłum. P. Podmiotło, Wydawnictwo Claroscuro, Warszawa 2007, 344 ss.

Pielewin W., Napój ananasowy dla pięknej damy, tłum. E. Rojewska-Olejarczuk, Warszawa, Grupa Wydawnicza Foksal, 2014, 320 ss.

Pietruszewska L., Jest noc, tłum. J. Czech, Wołowiec, Wydawnictwo Czarne, 2012, 128 ss.

Płuciennik M., Pacjent kontra choroba, czyli słów kilka o postawach wobec choroby, http://www.psychologia.net.pl/artykul.php?level=621 [dostęp: 03.01.2016]. Przyjaźn, ,Journal of Consumer Research”, [w:] http://www.eurekalert.org/put_releases/2006-01/uo=p=yf01300,php [dostęp: 04.02.2016].

Sałajczykowa J., Dziesięciolecie przemian. Proza rosyjska lat 1985-1995, Wydawnictwo Uniwersytetu Gdańskiego, Gdańsk 1998, 211 ss.

Scheller M., Cierpienie, śmierć, dalsze życie. Pisma wybrane, thum. A. Węgrzycki, Warszawa PWN, 1994, 141 ss.

Senczin R., Rodzina Jottyszewów, thum. M. Hornung, Warszawa, Noir Sur Blanc, 2015, 240 ss.

Sulima R., Antropologia codzienności, Kraków, Wydawnictwo Uniwersytetu Jagiellońskiego 2000, 194 ss.

Steuden S., Z psychologicznej problematyki zdrowia $i$ choroby, tłum. W.P. Oleś, Lublin, Towarzystwo Naukowe KUL, 2002, 311 ss.

Sztompka P., Życie codzienne - temat najnowszej socjologii, [w:] Socjologia codzienności, red. P. Sztompka, M. Bogunia-Borowska, Kraków, Wydawnictwo Znak, 2008, ss. 20-39.

Szyszkin M., Nie dochodza tylko listy nienapisane, thum. M. Hornung, Warszawa, Noir Sur Blanc, 2013, 278 ss.

Ulicka L., Zielony namiot, tłum. Redlich, Warszawa, Świat Książki, 2013, 688 ss.

Waszkielewicz H., Чернушная и прекрасная. Twórczość Ludmity Pietruszewskiej, Collegium Columbinum, Kraków 2007, 262 ss.

Wyspiański D., Heroizm dnia codziennego wedtug Philipa Zimbardo, „Charaktery” (Kielce), 2015, nr 11, ss. 21-25.

Берлин И., Воспоминания об Анне Ахматовой, Москва, Советскмй пмсатель, 1991, 453 ss.

Шорэ Э., Судьба трех поколений, или От очарования к разочарованию (по произведениям А. Коллонтай и Л. Петрушевской), http://www.a-z.ru/women cdtm1/h 1/preobrazh_5_1997_1.htm [dostęp: 25.03.2016]. 


\section{References}

Achmatowa A., Requiem [Requiem], [in:] eadem, Droga wszystkiej ziemi. Poezjaproza - dramat [The Way of whole Earth. Poetry - Prose - Drama], trans. A. Pomorski, Warszawa, OPEN, 2007, pp. 82-90.

Bąk-Sosnowska M., Choroby przewlekłe - dlaczego zmieniaja życie i jak sobie z nimi radzić [Chronic Diseases - Why They Change Life and how to Cope with them], Available at: http://zakladpsychologii.sum.edu.pl/?r=artykul/view\&id=26 [accessed: 28.12.2015].

Berlin I., Vospominaniia ob Anne Akhmatovo [Memories about Anna Akhmatova]. Moskva. Sovetskii pisatel', 1991, 453 pp.

Błaszkowski M., Czas. Czy rzeczywiście przemija? [The Time. Does It Really Go by?], Availavble at: http://marekblaszkowski.salon24.pl/137517.czas-czy-rzeczywiscie [accessed: 16.02.2016].

Bogunia-Borowska M. ,Fundamenty dobrego społeczeństwa. Wartości [Foundations of a Good Society. Values], Kraków, Znak, 2015, 381 pp.

Czubalski K., Wplyw choroby na stan psychiczny i zachowanie czlowieka chorego. Sztuka leczenia [The Effect of Diseases on Psychical Conditio and Behaviour of Ill Man. The Art of Treating], Gdańsk, Gdańskie Wydawnictwo Psychologiczne, $1995,325 \mathrm{pp}$.

Darska B., Życie bezradne (L. Pietruszewska, „Jest noc”) [The Helpless Life (L. Petrushevska. „There Is a Night”)] Available at: http://onet.p1/2012/05/27//zyciebezradne..., [accessed: 25.03.2016].

Dziewiecki M., Przyjaźń w czasach nieprzyjaznych dla przyjaźni [The Friendship in an Unfriendly Period Towards Friendship], Available at: http://www.opoka.org. pl/biblioteka/I/IP/md_przyjazn2011_4html [accessed: 10.09.2015].

Frankl V.E., Homo patiens, trans. M. Płuciennik, Warszawa, Instytut Wydawniczy PAX, 1998, $321 \mathrm{pp}$.

Gosden Ch., Social Being and Time, Oxford, Blackwell, 1994, 232 pp.

Heszen J., Sęk H., Psychologia zdrowia [The Heath Psychology], Warszawa, PWN, 2009, 371 pp.

Ingarden R., Ksiqżeczka o człowieku [The Booklet about Man], Kraków, Wydawnictwo Literackie, 1987, $176 \mathrm{pp}$.

Jewdokimow A., Europa po deszczu [Europe after the Rain], [in:] N. Smirnowa, J. Goumen (Eds.), Moskwa Noir [Moscow Noir], trans. E. Skórska, Warszawa, Wydawnictwo Claroscuro, 2011, pp. 211-253.

Jędrzejewska A., Rusinek A., Choroba dziecka - krzywda czy wyzwanie? [The Disease of Child - Harm or Challenge?], "Przyjaciel" 2007, no. 2. 
Jourard M., Diclosing Man to Himself. Toronto, D. Van Nostrand Company, 1968, $236 \mathrm{pp}$.

Kopka J., Czas a moralność. Od filozoficznych do socjologicznych koncepcji czasu [Time vs Moralisty. From Philosophical to Sociological Time Conception], "Acta Universitatis Lodziensis. Folia Sociologica" 2005, no 5, pp. 38-50.

Kucewicz K., Heroizm dnia codziennego [The Heroizm of Everyday Life], Available at: http://katarzynakucewicz.blox.p1/2012/12/Heroizm-dnia-codziennego... [accessed: 30.03.2016].

Minajew S., Duchless. Opowieść o nieprawdziwym człowieku [Duchess. The Story about False Man], trans. P. Podmiotło, Warszawa, Wydawnictwo Claroscuro, 2007, 344 pp.

Pielewin W., Napój ananasowy dla pięknej damy [The Pineapple Drink for Beautiful Lady], trans. E. Rojewska-Olejarczuk, Warszawa, Grupa Wydawnicza Foksal, 2014, 320 pp.

Pietruszewska L., Jest noc [There is a Night], trans. J. Czech, Wołowiec, Wydawnictwo Czarne, 2012, 128 pp.

Płuciennik M., Pacjent kontra choroba, czyli stów kilka o postawach wobec choroby [The Patient vs. disease or some Words about Attitudes towards Disease], Available at: http://www.psychologia.net.pl/artykul.php?level $=621$ [accessed: 03.01.2016].

Przyjaźń [Friendship]. ,Journal of Consumer Research”, Available at: http://www.eurekalert.org/put_releases/2006-01/uo=p=yf01300,php [accessed: 12.09.2014].

Sałajczykowa J., Dziesięciolecie przemian. Proza rosyjska lat 1985-1995 [The Decade of Transformation. The Russian Prose 1985-1995], Gdańsk, Wydawnictwo Uniwersytetu Gdańskiego, 1998, 211 pp.

Scheller M., Cierpienie, śmierć, dalsze życie. Pisma wybrane [Suffering, Heath, Further Life], trans. A. Węgrzycki, Warszawa, PWN, 1994, 141 pp.

Senczin R., Rodzina Joltyszewów [The Yoltishevs], trans. M. Hornung, Warszawa, Noir Sur Blanc, 2015, 240 pp.

Sulima R., Antropologia codzienności [Anthropology of Everyday Life], Kraków, Wydawnictwo Uniwersytetu Jagiellońskiego, 2000, 194 pp.

Shore E., Sud'ba trekh pokolenii, ili Ot ocharovaniia k razocharovaniiu (po proizvedeniiam A. Kollontai i L. Petrushevskoi), Available at: http://www.a-z.ru/women_cdtm1/h 1/preobrazh_5_1997_1.htm [accessed: 25.03.2016].

Steuden S.,Z Z psychologicznej problematykizdrowiai choroby [From the Psychological View of Health and Disease], trans. W.P. Oleś, Lublin, Towarzystwo Naukowe KUL, 2002, $311 \mathrm{pp}$.

Sztompka P., Życie codzienne - temat najnowszej socjologii [Everyday Life - the Subject of the most Modern Socjology], Socjologia codzienności [Socjology of 
Everyday Life], P. Sztompka, M. Bogunia-Borowska (Eds.), Socjologia codzienności [Socjology of Everyday Life], Kraków, Wydawnictwo Znak, 2008, pp. 20-39.

Szyszkin M., Nie dochodza tylko listy nienapisane [Only Unwritten Letters Do Not Arrive], trans. M. Hornung, Warszawa, Noir Sur Blanc, 2013, 278 pp.

Ulicka L., Zielony namiot [The Green Tent], trans. K. Redlich, Warszawa, Świat Książki, 2013, 688 pp.

Waszkielewicz H., Chernushnaia i prekrasnaia. Twórczość Ludmity Pietruszewskiej [Tshernusshnaya i Prekrassnaya. The Output by Ludmila Petrushevskaya], Kraków, Collegium Columbinum, 2007, 262 pp.

Wyspiański D., Heroizm dnia codziennego wedtug Philipa Zimbardo [The Heroizm of Everyday Life According to Philips Zimbardo, "Charaktery" (Kielce) 2015, no. 11, pp. 21-25. 